\title{
Analisis Data Pergerakan Harga Saham Bank BUMN melalui Debt to Equity Ratio (DER), Return On Equity (ROE) dan Earning Per Share (EPS)
}

\author{
Hairul Anam ${ }^{1}$, Saiful Ghozi ${ }^{2 *}$, Aditya Achmad Rakim³ \\ Winarni $^{4}$ \\ ${ }^{I}$ Mahasiswa Jurusan Akuntansi, Politeknik Negeri Semarang \\ ${ }^{2}$ Prodi Perbankan dan Keuangan, Politeknik Negeri Balikpapan \\ ${ }^{3}$ Prodi Perbankan dan Keuangan, Politeknik Negeri Balikpapan \\ ${ }^{4}$ Jurusan Akuntansi, Politeknik Negeri Semarang \\ saiful.ghozi@poltekba.ac.id
}

\begin{abstract}
Abstrak
Tujuan dari penelitian ini adalah untuk mengetahui perngaruh Debt to Equity Ratio (DER), Return On Equity (ROE) dan Earning Per Share (EPS) terhadap Harga Saham. Data diperoleh dari Annual Reportyang diterbitkan oleh Bursa Efek Indonesia dengan periode 2009-2017. Bank yang dijadikan sampel penelitian ini adalahBank Badan Usaha Milik Negara yang terdaftar di Bursa Efek Indonesia periode 2009-2017. Teknik analisis yang digunakan dalam penelitian ini adalah analisis regresi linier berganda untuk memperoleh gambaran yang menyeluruh mengenai hubungan antar variabel satu dengan variabel lainnya. Berdasarkan hasil pengujian hipotesis dengan menggunakan uji simultan (F) statistik menyimpulkan bahwa ketiga variabel bebas (DER, ROE, dan EPS) secara simultan berpengaruh signifikan terhadap variabel terikat, yakni Harga Saham. Demikian juga secara parsial, dimana ketiga variabel tersebut berpengaruh signifikan. Nilai $\mathrm{R}^{2}$ sebesar 0.801 yang diperoleh menunjukkan bahwa $80.1 \%$ dari perubahan nilai Harga Saham dipengaruhi oleh variabel bebas dalam penelitian, dan sisanya sebesar $19.9 \%$ dipengaruhi oleh variabel lain di luar model.

Kata kunci : harga saham, DER, ROE, EPS
\end{abstract}

\begin{abstract}
The purpose of this study was to determine the effect of Debt to Equity Ratio (DER), Return On Equity (ROE) and Earning Per Share (EPS) on Stock Prices. Data were obtained from the Annual Report issued by the Indonesia Stock Exchange with the 2009-2017 period. In this study used saturated sampling techniques and samples in the study are State-Owned Enterprised Banks listed on the Indonesia Stock Exchange for the period 2009-2017. The analysis technique used in this study is multiple linear regression analysis to obtain a comprehensive picture of the relationship between variables one with other variablesBased on the results of testing hypotheses using simultaneous test $(F)$ statistics concluded that Debt to Equity Ratio (DER), Return On Equity (ROE) and Earning Per Share (EPS) simultaneously had a significant effect on Stock Prices. Based on partial test $(t)$ it was concluded that Debt to Equity Ratio (DER), partially significant effect on Stock Price, Return On Equity (ROE) partially significant effect on Stock Price and Earning Per Share (EPS) partially significant effect on Stock Price.

Keywords :Stock Prices, Debt to Equity Ratio (DER), Return On Equity (ROE) and Earning Per Share (EPS).
\end{abstract}

\section{Pendahuluan}

Harga saham merupakan salah satu tolak ukur keberhasilan suatu perusahaan dalam mengelola perusahaannya. Harga saham suatu perusahaan mencerminkan nilai perusahaan di mata investor apabila harga saham suatu perusahaan tinggi maka nilai perusahaan di mata investor juga baik, hal ini dikarenakan investor atau calon investor memiliki kepercayaan lebih terhadap perusahaan yang berhasil mengelola perusahaanya, dan sebaliknya. Pergerakan harga saham merupakan naik dan turunnya harga saham di bursa saham yang dipengaruhi beberapa faktor, dimana peningkatan dan penurunan harga saham mencerminkan kinerja perusahaan. Pengukuran kinerja keuangan perusahaan dapat dilakukan menggunakan analisis fundamental, 
investor dapat menganalisis laporan neraca, laporan rugi laba, laporan perubahan modal, laporan arus kas serta analisis rasio keuangan. Hasil perhitungan analisis rasio tersebut dijadikan sebagai dasar dalam mengambil keputusan untuk berinvestasi.

Salah satu sektor yang terdaftar di pasar modal pada Bursa Efek Indonesia adalah sektor perbankan. Saham sektor perbankan yang terdaftar pada Bursa Efek Indonesia diantaranya saham Bank Umum Swasta, saham Bank Pembangunan Daerah, saham Bank Umum Syari'ah, serta saham Bank Umum Milik Negara. Manajemen dituntut untuk meningkatkan kinerja sehingga memaksimumkan nilai perusahaan bagi shareholder (Harmono, 2009). Hasil atas peningkatan kinerja pada sektor-sektor perbankan dapat dilihat melalui permintaan kredit baik konsumsi masyarakat maupun kredit investasi korporasi cukup mengalami perkembangan dari tahun ke tahun, membaiknya kualitas kredit yang tercermin pada penurunan rasio kredit bermasalah (non performing loan/NPL), membaiknya sindikasi kredit untuk membiayai infrastruktur pemerintah, serta pertumbuhan laba per lembar saham dari tahun ke tahun pada sektor perbankan. Peningkatan-peningkatan kinerja sektor perbankan tersebut berbanding terbalik pada harga saham sektor perbankan BUMN yang sempat mengalami beberapa kali penurunan harga.

Penelitian yang dilakukan Novasari (2013) menunjukkan bahwa variabel DER secara parsial berpengaruh signifikan terhadap harga saham, namun variabel EPS secara parsial tidak berpengaruh dan tidak signifikan terhadap harga saham. Sedangkan variabel EPS dan DER secara simultan berpengaruh signifikan terhadap harga saham. Penelitian Qoribulloh (2013), sejalan dengan penelitian Nordiana dan Budiyanto (2017) dimana hasil penelitian tersebut membuktikan bahwa secara parsial Return On Equity (ROE) berpengaruh signifikan terhadap harga saham. Egam, Ilat dan Pangerapan (2017) menemukan adanya perbedaan hasil penelitian antara variabel EPS, ROE dan harga saham. Hasil menunjukan bahwa variabel EPS secara parsial berpengaruh positif signifikan terhadap harga saham, variabel ROE secara parsial tidak berpengaruh terhadap harga saham, serta variabel ROA, ROE, dan EPS secara simultan berpengaruh signifikan terhadap harga saham

Berdasarkan latar belakang diatas, dan penelitian terdahulu yang menunjukkan perbedaan hasil penelitian yang terjadi, maka penelitian ini dilakukan untuk dapat mengetahui kebenaran pengaruh rasio keuangan terhadap harga saham pada sektor perbankan BUMN yang terdaftar pada Indeks Harga Saham Gabungan.

\section{Metodologi}

\subsection{Variabel}

Variabel dependen pada penelitian ini adalah harga saham, sedangkan variabel independen pada penelitian ini diantaranya Retrun on Equity (ROE), Debt To Equity Ratio (DER), serta Earning Per Share (EPS).

\section{Debt to Equity Ratio (DER).}

Rasio ini berfungsi untuk mengetahui berapa bagian dari setiap rupiah modal yang dijadikan sebagai jaminan utang (Hery, 2014:168). Besarnya hutang yang ada dalam permodalan perusahaan sangat mempengaruhi tinggi atau rendahnya laba yang diperoleh perusahaan. Semakin tinggi DER menunjukkan tingginya ketergantungan permodalan perusahaan terhadap pihak luar, sehingga beban perusahaan juga semakin berat (Sutrisno, 2012:218). Bagi kreditor apabila semakin tinggi nilai rasio ini berarti menggambarkan kondisi tidak menguntungkan karena akan semakin besar resiko yang akan ditanggung atas kegagalan yang mungkin terjadi. Perhitungan debt to equity ratio bisa menggunakan rumus sebagai berikut.

$$
\text { Debt to Equity Ratio }=\frac{\text { Total Utang }}{\text { Modal }} \times 100 \%
$$




\section{Return On Equity (ROE)}

Rasio ini menunjukan bahwa semakin baik rasio profitabilitas maka semakin baik menggambarkan kemampuan tingginya perolehan keuntungan perusahaan (Fahmi, 2013:135). Rasio ini menunjukkan efisiensi penggunaan modal sendiri.Semakin tinggi rasio ini, semakin baikposisi pemilik perusahaan semakin kuat, demikian pula sebaliknya. Rumus untuk mencari Return On Equity (ROE) dapat digunakan sebagai berikut.

$$
\text { Return On Equity }(R O E)=\frac{\text { Earning After Interest and Tax }}{\text { Equity }}
$$

\section{Earning Per Share (EPS)}

Pendapatan per lembar saham adalah bentuk pemberian keuntungan yang diberikan kepada para pemegang saham dari setiap lembar saham yang dimiliki (Fahmi, 2013:138). Nilai rasio ini sangat penting bagi pemegang saham karena menunjukkkan seberapa besar laba yang diperoleh dari per lembar saham yang beredar. Rasio ini dapat menunjukkan tingkat kesejahtraan perusahaan, apabila nilai rasio Earning Per Share (EPS) yang dibagikan kepada para investor tinggi maka menandakan bahwa perusahaan tersebut mampu memberikan tingkat kesejahteraan yang baik kepada pemegang saham, sedangkan Earning Per Share (EPS) yang dibagikan rendah maka menandakan bahwa perusahaan tersebut tidak mampu memberikan profit yang diharapkan pemegang saham. Perhitungan Earning Per Share bisa menggunakan rumus sebagai berikut.

Dimana :

$$
E P S=\frac{\text { EAT }}{I_{S b}}
$$

EPS = Earning Per Share

EAT = Earning After Tax atau pendapatan setelah pajak

$\mathrm{J}_{\mathrm{sb}} \quad=$ Jumlah Saham yang beredar

\section{Harga Saham}

Harga saham merupakan harga yang terjadi di pasar saham, harga saham akan sangat berarti bagi perusahaan karena harga tersebut menentukan besarnya nilai perusahaan. Menurut Tandelilin (2007: 19) dalam Suharno (2016) harga saham merupakan harga yang terjadi di pasar saham, akan sangat berarti bagi perusahaan karena harga tersebut menentukan besarnya nilai perusahaan. Harga saham merupakan salah satu indikator keberhasilan dalam pengelolaan perusahaan sehingga semakin tinggi harga saham yang ada di pasar atas suatu perusahaan tertentu maka dapat diartikan perusahaan tersebut dapat mengelola aktiva dengan baik.

\subsection{Jenis Data dan Metode Pengumpulan Data}

Populasi dalam penelitian ini adalah Bank Badan Usaha Milik Negara (BUMN) yang terdaftar di Bursa Efek Indonesia Periode 2009-2017. Teknik sampling yang digunakan dalam penelitian ini adalah teknik sampling jenuh dimana obyek penelitian merupakan semua Bank BUMN yang Terdaftar di Bursa Efek Indonesia Periode 2009-2017, yaitu: Bank BNI, Bank BRI, Bank BTN dan Bank Mandiri. Dalam penelitian ini menggunakan jenis data sekunder yangdiperoleh diperoleh melalui situs resmi Bursa Efek Indonesia yaitu www.idx.co.id, serta data harga saham yang diperoleh dari situs www.yahoofinance.com 


\subsection{Teknik Analisis Data}

Metode statistik yang digunakan untuk menganalisis data ada dua yaitu analisis statistik deskriptif dan analisis statistik inferensial. Analisis statistik deskriptif dalam penelitian ini berupa penyajian variabel- variabel penelitian dalam bentuk grafik untuk mempermudah analisis secara visual. Metode analisis data lebih lanjut yang digunakan dalam penelitian ini adalah analisis statistik infrensial yakni analisis regresi linier berganda. Analisis tersebut untuk menguji signifikansi pengaruh masing-masing variabel prediktor secara parsial dan simultan melalui uji t dan uji F. Terlebih dahulu dilakukan uji prasyarat analisis, yaitu (1) uji normalitas, (2) uji multikolineritas, (3) uji heteroskedastisitas, dan (4) uji autokorelasi. Model persamaan regresi yang terbentuk adalah $Y=a+b_{1} X_{1}+b_{2} X_{2}+b_{3} X_{3}$ dimana :

$\mathrm{Y}$ adalah Harga Saham

$\mathrm{X}_{1}$ adalah Debt to Equity Ratio (DER),

$\mathrm{X}_{2}$ adalah Return On Equity (ROE)

$\mathrm{X}_{3}$ adalah Earning Per Share (EPS)

\section{Hasil dan Pembahasan}

\subsection{Analisis Statistik Deskriptif}

1. Pergerakan Harga Sahampada Bank Umum Milik Negara Periode 2009-2017

Berikut adalah pergerakan harga saham yang terjadi pada Bank Umum Milik Negara yang terdaftar di Bursa Efek Indonesia periode 2009-2017.

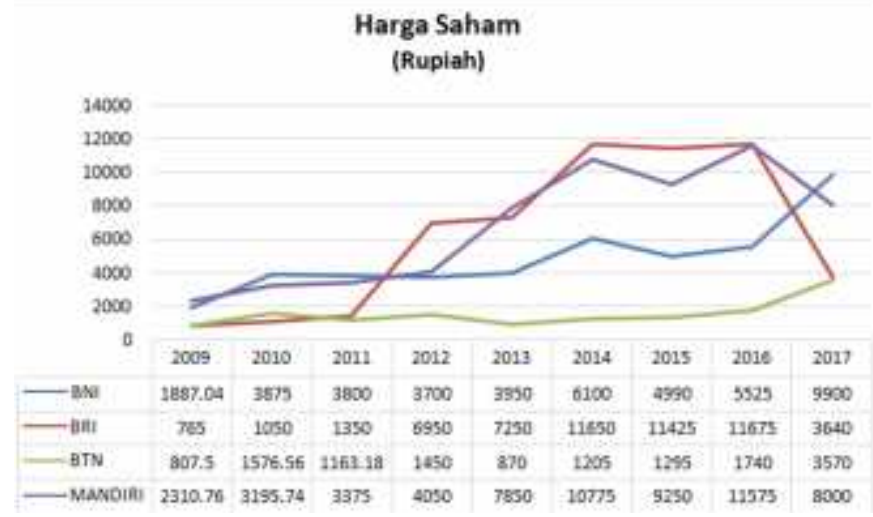

Gambar 1. Pergerakan Harga Saham pada Bank Umum Milik Negara yang Terdaftar di Bursa Efek Indonesia Periode 2009-2017

Gambar 1 diatas memperlihatkan pergerakan harga saham Bank Umum Milik Negara yang terdaftar di Bursa Efek Indonesia periode 2009-2017. Harga saham Bank BNI Tbk, dari tahun 2009 sampai tahun 2014 mengalami peningkatan, pada tahun 2014 mengalami sedikit penurunan sebesar Rp 1.110 kemudian mengalami peningkatan kembali tahun 2016 dan tahun 2017. Sedangkan harga saham pada Bank BTN dari tahun 2009 sampai tahun 2012 mengalami peningkatan, meskipun pada tahun 2012 ke tahun 2013 mengalami penurunan sebesar Rp 580 . Selanjutnya harga saham pada Bank Mandiri dari tahun 2009 sampai tahun 2014 juga secara umum mengalami peningkatan, dan peningkatan nilai harga saham yang cukup siginifikan terjadi tahun 2012 yaitu sebesar Rp 3.800, secara umum peningkatannya relatif stabil. 
2. Pergerakan Debt to Equity Ratio (DER) pada Bank Umum Milik Negara Periode 2009-2017

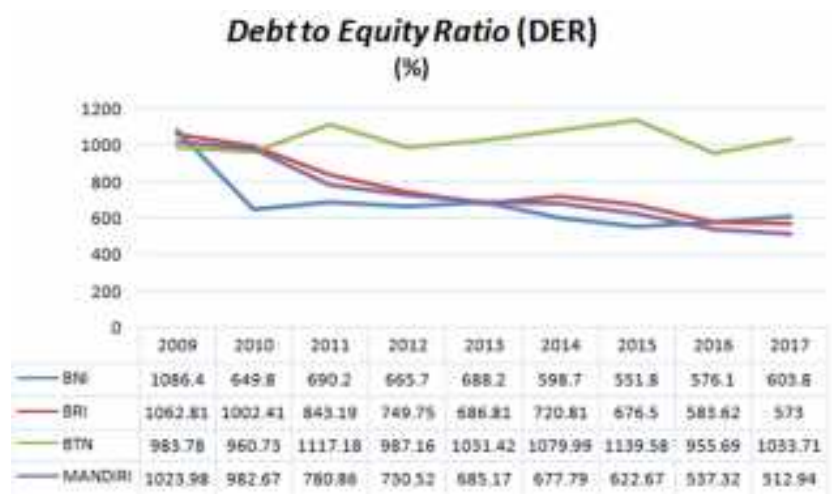

Gambar 2. Grafik Debt to Equity Ratio

Berdasarkan Gambar 2, rasio DER PT Bank Negara Indonesia Tbk mengalami penurunan pada tahun 2009 sebesar 434.6\% kemudian dari tahun 2010 sampai tahun 2017 nilai DER mengalami naik-turun yang relatif stabil. Pada PT Bank Rakyat Indonesia Tbk, nilai rasio DER mengalami penurunan dari tahun 2009 sampai tahun 2013 namun mengalami peningkatan dari tahun 2013 ke tahun 2014 sebesar 34\% dan mengalami penurunan kembali dari tahun 2015 hingga tahun 2017. Pada PT Bank Tabungan Negara Tbk, nilai rasio DER mengalami naik-turun yang relatif stabil dari tahun 2009 sampai tahun 2017. Kemudian pada PT Bank Mandiri Tbk, nilai rasio DER mengalami penurunan dari tahun 2009 sampai tahun 2017. Secara umum nilai DER keempat bank BUMN mengalami penurunan tipis yang relative stabil. Hanya bank BTN yang mengalami nilai yang relative stabil.

3. Pergerakan Return On Equity (ROE) pada Bank Umum Milik Negara Periode 2009-2017

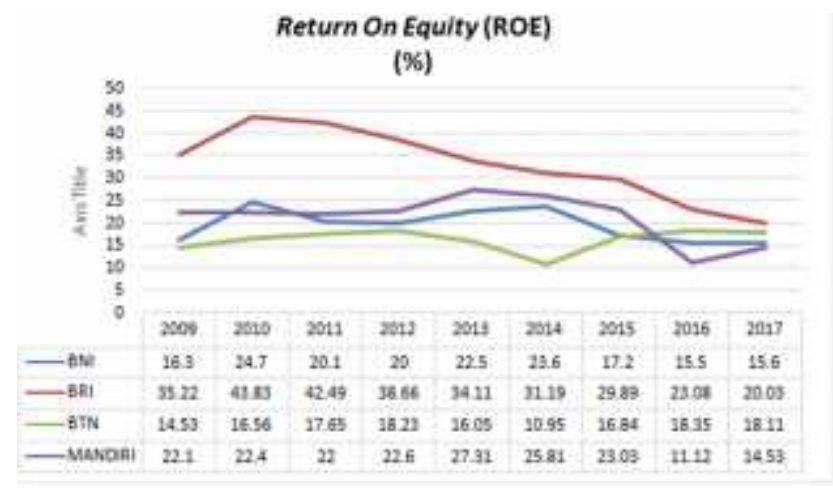

Gambar 3. Grafik Return On Equity (ROE)

Berdasarkan Gambar 3 diatas, rasio ROE PT Bank Negara Indonesia Tbk mengalami peningkatan dari tahun 2009 ke tahun 2010 sebesar 8.4\% kemudian dari tahun 2011 sampai tahun 2017 nilai $R O E$ mengalami naik-turun yang relatif stabil. Pada PT Bank Rakyat Indonesia Tbk, nilai rasio $R O E$ mengalami peningkatan dari tahun 2009 ke tahun 2010 sebesar $8.61 \%$ namun mengalami naik-turun yang relatif stabil dari tahun 2010 sampai tahun 2017. Pada PT Bank Tabungan Negara Tbk, nilai rasio $R O E$ mengalami peningkatan dari tahun 2009 sampai tahun 2012, namun nilai $R O E$ mengalami penuruan dari tahun 2012 ke tahun 2013 sebesar 5.1\% dan 
mengalami peningkatan kembali dari tahun 2015 sampai tahun 2017. Kemudian pada PT Bank Mandiri Tbk, nilai rasio ROE mengalami naik-turun yang relatif stabil dari tahun 2009 sampai tahun 2015 dan mengalami penurunan dari tahun 2015 ke tahun 2016 sebesar $11.92 \%$ dan mengalami peningkatan dari tahun 2015 samapi tahun 2017.

4. Pergerakan Earning Per Share (EPS) Pada Bank Umum Milik Negara Periode 2009-2017

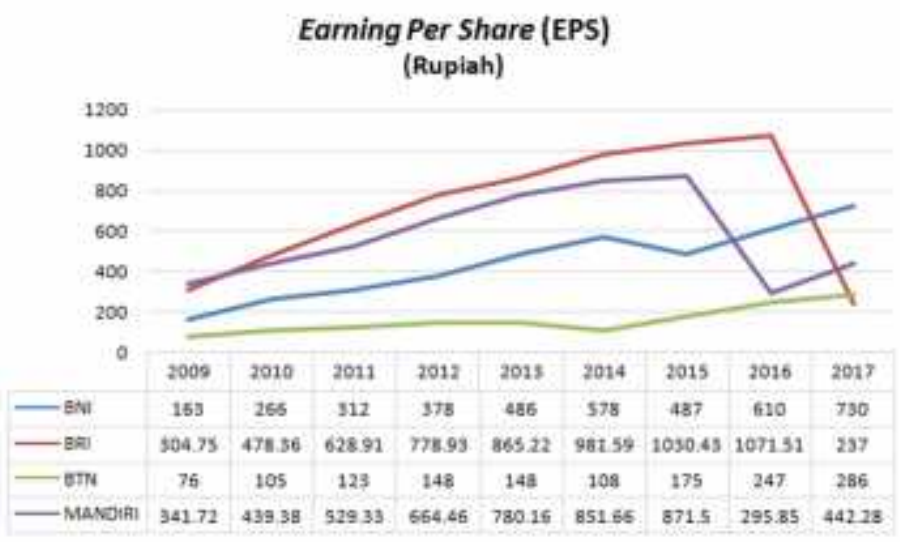

Gambar 4. Grafik Earning Per Share

Berdasarkan Gambar 4 diatas, rasio EPS PT Bank Negara Indonesia Tbk mengalami peningkatan dari tahun 2009 sampai tahun 2017. Pada PT Bank Rakyat Indonesia Tbk, nilai rasio EPS mengalami peningkatan dari tahun 2009 sampai tahun 2016 namun mengalami penurunan yang cukup signifikan dari tahun 2016 ke tahun 2017 sebesar Rp 840.51. Pada PT Bank Tabungan Negara Tbk, nilai rasio Earning Per Share (EPS) mengalami naik-turun yang relatif stabil dari tahun 2009 sampai tahun 2017. Kemudian pada PT Bank Mandiri Tbk, nilai rasio EPS mengalami peningkatan dari tahun 2009 sampai tahun 2015 namun mengalami penurunan pada tahun 2015 ke tahun 2017 sebesar Rp 575.65 dan mengalami peningkatan kembali dari tahun 2016 ke tahun 2017.

\subsection{Uji Asumsi Klasik}

Berdasarkan Tabel 1 berikut diperoleh bahwa data yang akan dianalisis telah memenuhi uji prasyarat analisis regresi berganda.

Tabel 1. Hasil Pengujian Asumsi Klasik

\begin{tabular}{lcl}
\hline Uji Normalitas & Hasil & Keterangan \\
\hline $\begin{array}{l}\text { Kolmogorov-Smirnov Z } \\
\text { Asymp. Sig. (2-tailed) of KS }\end{array}$ & $\begin{array}{c}0,810 \\
\text { p-value }=0,528(>0.05)\end{array}$ & $\begin{array}{l}\text { Data berdistribusi } \\
\text { normal }\end{array}$ \\
\hline Uji Autokorelasi & & \\
\hline Durbin-Watson & $1,2953(\mathrm{dl}) \leq 1,578 \leq 1,6539(\mathrm{du})$ & $\begin{array}{l}\text { No desicison } \\
\text { Residual random atau } \\
\text { Asymp. Sig. (2-tailed) of Run Test } \\
\text { p-value }=0,612(>0.05)\end{array}$ \\
& & antar residual \\
\hline Uji Multikolininieritas & & $\begin{array}{l}\text { Tidak ada } \\
\text { multikolinieritas }\end{array}$ \\
\hline Variance Inflation Faktor (VIF) DER & $1,885(<10)$ & \\
Variance Inflation Faktor (VIF) ROE & $1,644(<10)$ & \\
Variance Inflation Faktor (VIF) EPS & $2,560(<110)$ & \\
\hline
\end{tabular}




\begin{tabular}{lll}
\hline Uji Heteroskedastisitas (Uji Glejser) & & \\
\hline Debt to Equity Ratio (DER) & $0,090(<0.05)$ & Homoskedastisitas \\
Return On Equity (ROE) & $0,760(<0.05)$ & \\
Earning Per Share (EPS) & $0,996(<0.05)$ & \\
\hline
\end{tabular}

Sumber : Hasil Olah Data

\subsection{Pengujian Hipotesis}

\subsubsection{Uji Koefisien Determinasi $\left(R^{2}\right)$}

Berikut output analisis data SPSS 20 dari uji koefiisien determinasi yang dilakukan.

Tabel 2. Hasil Koefisien Determinasi Model Summary ${ }^{\text {b }}$

\begin{tabular}{|c|c|c|c|c|c|}
\hline $\begin{array}{l}\text { Mode } \\
1\end{array}$ & $\mathrm{R}$ & $\begin{array}{c}\mathrm{R} \\
\text { Square }\end{array}$ & $\begin{array}{c}\text { Adjusted R } \\
\text { Square }\end{array}$ & $\begin{array}{l}\text { Std. Error of } \\
\text { the Estimate }\end{array}$ & $\begin{array}{l}\text { Durbin- } \\
\text { Watson }\end{array}$ \\
\hline 1 & $.904^{\mathrm{a}}$ & .818 & .801 & 1630.87216 & 1.578 \\
\hline
\end{tabular}

a. Predictors: (Constant), EPS, ROE, DER

b. Dependent Variable: HARGASAHAM

Sumber: data diolah dari SPSS 20.0, 2018

Berdasarkan Tabel 2 didapatkan besarnya adjusted $\mathrm{R}$ adalah 0,818, hal ini berarti 81,8\% variasi harga saham dapat dijelaskan oleh variasi dari 3 (tiga) variabel independen (Return On Equity, Earning Per Share, Return On Equity). Sedangkan sisanya (100\%-81,8\% = 18,2 \%) dijelaskan oleh sebab-sebab lain diluar model yang tidak diteliti.

\subsubsection{Uji Simultan (Uji F)}

Berikut output analisis data SPSS 20 dari uji F yang dilakukan.

Tabel 3. Hasil Uji Simultan ANOVA $^{\mathrm{a}}$

\begin{tabular}{|c|c|c|c|c|c|c|}
\hline \multicolumn{2}{|c|}{ Model } & Sum of Squares & Df & Mean Square & $\mathrm{F}$ & Sig. \\
\hline \multirow{3}{*}{1} & Regression & 382323082.002 & 3 & 127441027.334 & 47.915 & $.000^{\mathrm{b}}$ \\
\hline & Residual & 85111808.086 & 32 & 2659744.003 & & \\
\hline & Total & 467434890.088 & 35 & & & \\
\hline
\end{tabular}

Sumber: data diolah dari SPSS 20.0, 2018

Berdasarkan Tabel 3 diperoleh nilai $F_{\text {hitung }}$ sebesar 47,915 dan $F_{\text {tabel }}$ sebesar 3,29sehingga $\mathrm{F}_{\text {hitung }}>\mathrm{F}_{\text {tabel }}$ yaitu 47,915>3,29 pada nilai p-value $=0,000$. Artinya, variable DER, ROE dan EPS secara bersama-sama memiliki pengaruh signifikan terhadap harga saham pada perbankan BUMN di Bursa Efek Indonesia. 


\subsubsection{Hasil Parsial (Uji t)}

Berikut output analisis data SPSS 20 dari uji t yang dilakukan.

Tabel 4 Uji Parsial

Coefficients $^{\mathrm{a}}$

\begin{tabular}{|c|c|c|c|c|c|c|}
\hline \multirow{2}{*}{\multicolumn{2}{|c|}{ Model }} & \multicolumn{2}{|c|}{$\begin{array}{c}\text { Unstandardized } \\
\text { Coefficients }\end{array}$} & \multirow{2}{*}{$\begin{array}{c}\begin{array}{c}\text { Standardized } \\
\text { Coefficients }\end{array} \\
\text { Beta }\end{array}$} & \multirow[t]{2}{*}{$\mathrm{t}$} & \multirow[t]{2}{*}{ Sig. } \\
\hline & & B & Std. Error & & & \\
\hline \multirow{4}{*}{1} & (Constant) & 7196.955 & 1790.787 & & 4.019 & .000 \\
\hline & DER & -4.663 & 1.888 & -.256 & -2.470 & .019 \\
\hline & ROE & -155.919 & 43.212 & -.349 & -3.608 & .001 \\
\hline & EPS & 10.320 & 1.513 & .823 & 6.822 & .000 \\
\hline
\end{tabular}

a. Dependent Variable: HARGA SAHAM

Sumber: data diolah dari SPSS 20.0, 2018

Berdasarkan Tabel 4 diatas, hasil uji parsial untuk masing-masing variabel independen dapat dijelaskan sebagai berikut.

\section{Pengaruh Debt to Equity Ratio (DER) terhadap Harga Saham}

Uji parsial pengaruh variabel Debt to Equity Ratio (DER) diperoleh $\mathrm{t}_{\text {hitung }}>\mathrm{t}_{\text {tabel }}(-2.470>$ 2.037) dan nilai p-value 0.019 atau lebih kecil dari 0,05 maka dapat dinyatakan bahwa variabel Debt to Equity Ratio (DER) secara parsial berpengaruh signifikan terhadap Harga Saham.Penelitian ini sejalan dengan penelitian yang telah dilakukan oleh Novasari (2013), dan Egam, Ilat dan Pangerapan (2017) yang menyatakan bahwa Debt to Equity Ratio (DER) berpengaruh signifikan terhadap harga saham.

Rasio Debt to Equity Ratio (DER) perusahaan yang tinggi akan menyebabkan harga saham perusahaan menjadi rendah, hal ini dikarenakan jika perusahaan memperoleh laba maka perusahaan cenderung menggunakan laba tersebut untuk membayar pokok hutang beserta bunganya dibandingkan dengan membagi deviden, hal tersebut membuat minat investor untuk menanamkan modalnya di perusahaan menjadi rendah, sehingga menyebabkan harga saham akan turun.

\section{Pengaruh Return On Equity (ROE) terhadap Harga Saham}

Uji parsial pengaruh variabel Return On Equity (ROE) diperoleh nilai $\mathrm{t}_{\text {hitung }}>\mathrm{t}_{\text {tabel }}(-3.608>$ 2.037) dan nilai p-value 0.001 atau lebih kecil dari 0,05 maka dapat dinyatakan bahwa variabel Return On Equity (ROE) secara parsial berpengaruh signifikan terhadap Harga Saham. Penelitian ini sejalan dengan penelitian yang telah dilakukan oleh Qorilbulloh (2013), dan Nordiana dan Budiyanto (2017) yang menyatakan bahwa Return On Equity (ROE) berpengaruh signifikan terhadap harga saham.

Rasio Return On Equity (ROE) yang tinggi belum tentu disebabkan perusahaan memperoleh keuntungan yang tinggi, tetapi disebabkan oleh total ekuitas yang dimiliki perusahaan relatif rendah dibandingkan dengan hutang (modal asing) perusahaan. Hutang yang terlalu besar bisa membahayakan pemilik modal apabila tidak mampu membayar kembali hutang dan bunganya.

\section{Pengaruh Earning Per Share (EPS)terhadap Harga Saham}

Uji parsial pengaruh variabel Earning Per Share (EPS)memiliki nilai $t_{\text {hitung }}>t_{\text {tabel }}(6.822>$ 2.037) dan nilai p-value 0.000 atau lebih kecil dari 0,05 maka dapat dinyatakan bahwa variabel 
Earning Per Share (EPS) secara parsial berpengaruh signifikan terhadap Harga Saham Hasil tersebut relevan dengan hasil penelitian yang telah dilakukan oleh Qoribulloh (2013), dan Egam, Ilat dan Pangerapan (2017) dimana variabel Earning Per Share (EPS)secara parsial berpengaruh signifikan terhadap harga saham.

Semakin tinggi Earning Per Share (EPS) akan mempengaruhi minat investor untuk berinvestasi dikarenakan semakin besar laba yang didapatkan pemegang saham atas jumlah deviden yang akan diterima sehingga permintaan saham akan meningkat dan berdampak pada naiknya harga saham perusahaan tersebut.

\section{PengaruhSimultan Debt to Equity Ratio (DER), Return On Equity (ROE), Earning Per Share (EPS)terhadap Harga Saham}

Berdasarkan nilai Adjusted $R$ Square sebesar 0.818 atau $81.8 \%$ artinya bahwa ketiga variabel independen mempengaruhi variabel dependen yaitu Harga Saham sebesar 81,8\%, dan sisanya sebesar $18.2 \%$ dipengaruhi oleh variabel lain di luar model.

\section{Kesimpulan}

Harga saham merupakan salah satu tolak ukur keberhasilan suatu perusahaan dalam mengelola perusahaannya. Pergerakan harga saham merupakan naik dan turunnya harga saham di bursa saham yang dipengaruhi beberapa faktor, dimana peningkatan dan penurunan harga saham mencerminkan kinerja perusahaan. Peningkatan kinerja sektor perbankan yang sahamnya terdaftar pada Bursa Efek Indonesia, namun peningkatan kinerja tersebut berbanding terbalik pada harga saham sektor perbankan BUMN yang sempat mengalami beberapa kali penurunan harga. Berdasarkan hasil pengujian hipotesis diatas, dapat diambil kesimpulan rasio Debt to Equity Ratio (DER) yang tinggi akan menyebabkan harga saham perusahaan menjadi rendah, hal ini dikarenakan laba yang diperoleh perusahaan cenderung digunakan unttuk membayar hutang dibandingkan membagi deviden, rasio ROE yang tinggi belum tentu menunjukan ekuitas perusahaan tinggi sehingga menurunkan harga saham perusahaan, semakin tinggi EPS meningkatkan minat investor untuk memiliki saham tersebut sehingga meningkatkan harga saham perusahaan, serta ketiga variabel bebas (DER, ROE, dan EPS) secara simultan berpengaruh signifikan terhadap variabel terikat, yakni harga saham.

\section{Keterbatasan dan Saran}

Penelitian ini hanya memfokuskan pada saham-saham perbankan BUMN, penelitian lain dapat dikembangkan pada seluruh sektor perbankan pada BEI. Selain itu, penelitian ini hanya menggunakan analisis variabel independen Debt to Equity Ratio (DER), Return On Equity (ROE) dan Earning Per Share (EPS), penelitian kedepan dapat memasukan rasio-rasio analisis fundamental lain seperti Net Profit Margin (NPM), Return On Asset (ROA), Dividen Yield, Dividend Payout Ratio (DPR).

\section{Daftar Pustaka}

Arifin, Ali. 2004. Membaca Saham, Yogyakarta: Penerbit ANDI

Egam, Gerald Edsel Yermia, Ilat, Ventje dan Pangerapan, Sonny. 2017. Pengaruh $R O A, R O E$, NPM dan EPS terhadap harga saham pada perusahaan yang terdaftar di indeks LQ45 di Bursa Efek Indonesia periode 2012-2015. (Jurnal Online). Diakses 17 September 2017

Fahmi, Irfan. 2013. Analisis Laporan Keuangan, bandung : ALFABETA, CV

Fakhruddin, Hendy M. 2008. Istilah Pasar Modal, Jakarta: PT Elex Media Komputindo Kelompok Media. 
Ghozali, H. Imam. 2013. Aplikasi Analisis Multivariate dengan program IBM SPSS 21 Update PLS regresi edisi ketujuh, Semarang: Universitas Dipenogoro.

Ghozali, H. Imam. Ghozali. 2016, Aplikasi Analisis Multivariete Dengan Program IBM SPSS 23 Edisi ke delapan, Semarang: Badan Penerbit Universitas Diponegoro.

Halim, Abdul. 2005. Analisis Investasi, Jakarta: Salemba Empat (PT Salemba Emban Patria) Edisi kedua.

Halim, Abdul. 2005. Analisis Investasi, Jakarta: Salemba Empat (PT Salemba Emban Patria) Edisi kedua.

Harmono. 2009. Manajemen Keuangan Berbasis Balanced Scorecard (Pendekatan Teori, Kasus, dan Riset Bisnis). Jakarta: Bumi Aksara.

Hery. 2014 . Analisis Kinerja Manajemen. Jakarta:PT Grasindo.

Hery. 2015. Analisis Kinerja Manajemen, Jakarta: PT Grasindo.

https://m.bareksa.com./id/text/2018/02/01/bahana-rekomendasikan-beli-saham-4-bank-bumn-iniapa-alasannya/18276/news (diakses 12 Juni 2018).

Kasiram, H. Moh. 2010. Metode Penelitian Kualitatif- Kuantitatif, Malang: UIN-MALIKI PRESS cetakan II.

Kasmir, 2011, Bank dan Lembaga Keuangan Lainnya, Jakarta: PT RAJAGRAFINDO PERSADA.

Kasmir. 2011. Bank dan Lembaga Keuangan Lainnya cetakan ke sebelas, Jakarta: PT Rajagrafindo Persada.

Kasmir. 2013. Analisis Laporan Keuangan, Jakarta: PT RajaGrafindo Persada.

Kasmir. 2015. Analisis Laporan Keuangan, Jakarta: PT Rajagrafindo Persada.

Kasmir. 2016. Bank dan Lembaga Keuangan Lainnya Edisi Revisi 2014, Jakarta: PT Rajagrafindo Persada.

Lestari, Tri Puji. 2015. Pengaruh CAR, RORA, BOPO, EPS, LDR dan ROA terhadap harga saham PT. Bank OCBC NISP Tbk. Skripsi. Balikpapan: STIE Madani Balikpapan.

Martalena dan Maya Malinda. 2011. Pengantar Pasar Modal, Yogyakarta: ANDI.

Martono, Nanang. 2014. Analisis isi dan Analisis Data Sekunder, Jakarta: PT Rajagrafindo Persada.

Nordiana, Ariskha dan Budiyanto. 2017. Pengaruh DER, ROA dan ROE terhadap harga saham pada perusahaan food and beverage. (Jurnal Online).Diakses 14 Januari 2017.

Novasari, Ema. 2013. Pengartuh PER, EPS, ROA dan DER terhadap harga saham perusahaan sub sektor industri textile yang Go Public di Bursa Efek Indonesia pada tahun 20092011. Skripsi. Semarang: Universitas Negeri Semarang.

Oei, Istijanto. 2009. Kiat Investasi Valas, Emas, Saham, Jakarta: PT Gramedia Pustaka Utama.

Priyatno, Duwi. 2014. SPSS 22 Pengolah Data Terpraktis edisi kesatu, Yogyakarta: ANDI.

Qoribulloh, A.Rizal. 2013. Pengaruh rasio keuangan terhadap harga saham pada perusahaan manufaktur yang terdaftar di Bursa Efek Indonesia tahun 2011. Skripsi. Yogyakarta: Universitas Negeri Yogyakarta.

Santoso, Singgih. 2013. Menguasai SPSS 21 di Era Informasi, Jakarta: PT Elex Media Komputindo Kelompok Gramedia, Anggota IKAPI.

Sugiyono. 2012. Metode Penelitian Kuantitatif dan Kualitatif $R \& D$, Bandung: ALFABETA, cv.

Sugiyono. 2015. Metode Penelitian Kuantitatif dan Kualitatif dan $R$ \& $D$, Bandung: ALFABETA,.

Sugiyono. 2017. Statistika Untuk Penelitian, Bandung: ALFABETA, cv.

Sugiyono. 2016. Metode Penelitian Kuantitatif, kualitatif, dan R\&D, Bandung: ALFABETA, CV. 
Suharno, 2016.Pengaruh Harga Saham Terhadap Harga Saham Perusahaan Farmasi Yang Terdafatar di Bursa Efek Indonesia Periode 2010 - 2014.Skripsi. Yogyakarta: Universitas Negeri Yogyakarta.

Sunyoto, Danang. 2013. Analisis laporan keuangan untuk bisnis, Yogyakarta: CAPS (Center of Acedemic Publishing Service).

Sutedi, Adrian. 2013. Pasar Modal Mengenal Nasabah Sebagai Pencegahan Pencucian Uang, Bandung: ALFABETA, CV.

Sutrisno. 2012. Manajemen Keuangan Teori Konsep \& Aplikasi, Yogyakarta: EKONISIA.

Taswan, 2006, Manajemen Perbankan konsep, Teknik dan Aplikasi, Yogyakarta: UPP STIM YKPN YOGYAKARTA.

Umar, Husein. 2013. Metode Penelitian Untuk Skripsi dan Tesis Bisnis, Jakarta: PT Rajagrafindo.

www.bankmandiri.co.id

www.bni.co.id

www.bri.co.id

www.btn.co.id

www.idx.co.id

www.yahoofinance.co.id 